\title{
Effect of Aqueous Extracts of Punica Granatum and Quercus Infectoria against Penicillium Spp. and Cladosporium Spp.Mycelial Growth
}

\author{
Taha Jalal Omar zrari \\ Kurdistan region- Ministry of higher education and scientific research \\ Koya Unversity- Faculty of Science and Health-Dept. of Biology \\ Email: taha.jalal@koyauniversity.org
}

Received: November 18, 2014 Accepted: December 3, 2014

doi:10.5296/jbls.v6i1.6634 URL: http://dx.doi.org/10.5296/jbls.v6i1.6634

\begin{abstract}
The experiments were conducted during 2011-2012 in the laboratories of Biology Department, Faculty of Science and Health, University of Koya , Kurdistan region Iraq by using completely randomized design (CRD) with three replications. The effects of aqueous extracts of pomegranate (Punica granatum L.) and oak gall (Quercus infectoria L.) at concentrations were determined against $(0,10,20$ and $25 \%)$ of raw extracts to control growth of Penicillium spp. and Cladosporium spp. after different times of incubation. The results revealed that Penicillium spp. was more sensitive to both extracts than cladosporium spp.. The aim of the present study was to evaluate the antifungal activity of the two plant extracts (oak gall and pomegranate) against Penicillium spp. and Cladosporium spp.
\end{abstract}

Keywords: Antifungal activity, Penicillium spp., Cladosporium spp., Punica granatum, Quercus infectoria.

\section{Introduction}

The plant fungal diseases have traditionally been controlled by chemical fungicides. The development of resistant strains of pathogens against various chemical fungicides (Lin, K.C. 1981, Witte, W. 1998) and their harmful effects on soil biosphere, Sarmamy, A. O. I. (2001) make the use of these chemicals limited. Because of these problems associated with the use of chemicals, researchers are trying to use environmentally safe alternative methods of fungal controls to reduce synthetic fungicides side effects. Plant extracts are one of several non-chemical control alternatives that inspiring great interest due to their availability, non-toxicity and friendliness to the environment Aqil, F., M. Zahin, etal,(2010). A number of 
antifungal compounds of diverse skeletal patterns have been found in plants, these compounds belong mainly to six broad chemical groups such as phenol and phenolic acids, coumarins and pyrones, flavonoids, isoflavonoids, steroids, alkaloids, and miscellaneous compounds (Mitra, S.R., Choudhuri, A.and Adityachaudhury, N1984) . Penicillium spp. is an important post harvest pathogen that not only causes decay on fruits but also produces the carcinogenic mycotoxin patulin in spoiled fruit and processed fruit. Cladosporium spp. are pigmented moulds (dematicae) widely distributed in the air as well as decayed organic matter, and they are food contaminants. Some species are most widely distributed in the tropics and subtropics (Hoog GS,. etal, 2000 , Dixon DM, Polak-Wyss A, 1991). Plant extracts show antibacterial effects and antifungal activity against wide range of fungi (Sarmamy, A. O. I. ; Al-Juboory, B. A. 2005 Aba Alkhail, A. A. 2005 , Aba Alkhail, A. A. 2005 , Sarmamy A. O.I. ; Saleem, Z. K. 2009).

\section{Materials and Methods}

\subsection{Preparation of Fungi}

Penicillium spp. and Cladosporium spp. were isolated from infected kiwi and onion respectively. Pure cultures of the two isolated fungi were identified on the bases of morphological and microscopically characteristics according to the key of (Barnett and Hunter 1972 and Bessy 1968).

\subsection{Preparation of Extracts and Culture:}

The epicarp of pomegranate fruits and oak galls were obtained from the local market at koya city. They were washed and dried at room temperature, each plant parts were ground separately by mortal pestle and weight $50 \mathrm{gm}$ of the powder of each plant material were added to $100 \mathrm{ml}$ of distilled water and put in an electric shaker for $24 \mathrm{hrs}$. Plant extracts were filtered by passing them through four folded layers of gauze. The extracts $(50 \% \mathrm{w} / \mathrm{v}$ of each plant was used as stock solution) were kept in the refrigerator until use (Harborne, J. B. 1984) .

Table 1. Preparation of plant extracts concentrations

\begin{tabular}{|l|l|l|}
\hline Plant extract Concentration & Stock solution 50\% ml & Distilled water ml \\
\hline Control $0 \%$ & 0 & $20 \mathrm{ml}$ \\
\hline $10 \%$ & $4 \mathrm{ml}$ & $10 \mathrm{ml}$ \\
\hline $20 \%$ & $8 \mathrm{ml}$ & $10 \mathrm{ml}$ \\
\hline $25 \%$ & $10 \mathrm{ml}$ & 0 \\
\hline
\end{tabular}

After preparation of each concentration added to the sterilized potato dextrose agar medium (PDA) supplemented by the chloramphenicol was added to the media for preventing bacterial growth, mixed well then $20 \mathrm{ml}$ of the mixture (PDA medium + plant extract) were poured in each $9 \mathrm{~cm}$ Sterilized Petri dishes. The medium without extract was served as control $(0 \%)$.

Mycelial discs of fungi were prepared using a cork borer ( $5 \mathrm{~mm}$ diameter) from the margin of 5 days old culture of the two tested fungi and placed at the centre of Petri dishes. Each treatment 
was replicated three times. Plates were incubated in an incubator at $25^{\circ} \mathrm{C}$. Fungal growth after 5,7, and 9 days for Penicillium spp. and Cladosporium $s p$ was measured by taking the mean of the two diameters taken at right angles for each colony.

\section{Results and Discussion}

\subsection{Effects of Pomegranate Extract on Controlling Studied Fungi}

Effects of aqueous extract of pomegranate:

The results show in (Table 2) that the aqueous extract of pomegranate affected significantly the growth of mycelium of Penicillium spp. and Cladosporium sp. at all extract concentrations used (10, 20 and 25\%) by reducing the mycelial growth of Penicillium spp. and Cladosporium sp to 31.6 and $30-29 \mathrm{~mm}$ compared with control $(42.6 \mathrm{~mm})$ for the two fungi respectively. The growth of Penicillium sp and Cladosporium sp directly decrease according to concentration of plant extract $(10,20$ and $25 \%)$ respectively that is shown by decrease of diameter of fungal colony both fungal isolate as compare to the control, the diameter of colony at $25 \%$ is smaller than other because contains highly concentrated of inhibitory affect. The diameter of Cladosporium sp is smaller than the Penicillium sp because Penicillium growth faster and also may be due to difference between the two fungi in their genetic construction or may be due to the difference in the chemical and structural composition of the cell walls. Time of incubation also affected the growth of mycelia significantly and the effects of extracts reduced as the time increased. The mycelial growth was $20 \mathrm{~mm}$ after 5 and 7 days of application. Figure 1 shows significant interactions between time of incubation and extract concentrations, and the highest effect was at concentration of $25 \%$ and 5 days of incubation $(20 \mathrm{~mm})$ compared with control and 7 days of incubation $(30 \mathrm{~mm}$ ) for Penicillium spp. and $13 \mathrm{~mm}$ at concentration of $25 \%$ after 5 days of incubation compared with $43 \mathrm{~mm}$ in control after 7 days of incubation in case of Cladosporium spp. (Figure 2).

The time of incubation also affected the growth of mycelia significantly and the effect of extract reduced as a time increase. Oak gall containing tannins Paaverurve, V. M. ; Raal, A. (2010) which have inhibitory effect on fungi Vonshak, A. etal,(2003), while pomegranate antifungal activity may be due to polyphenols and punicalagins (Seeram, N. P.; etal, 2006). The result of affect of epicarp of pomegranate on the Penicillium sp and Cladosporium spp. is shown in the table (2). 


\section{Macrothink}

Journal of Biology and Life Science

ISSN 2157-6076

2015, Vol. 6, No. 1

Table 2. effect of aqueous extract of pomegranate on Penicillium sp and Cladosporium spp. on mycelia growth.

\begin{tabular}{|c|c|c|c|}
\hline \multicolumn{2}{|c|}{ Treatment } & \multicolumn{2}{c|}{ Fungal species } \\
\hline \multirow{4}{*}{$\begin{array}{c}\text { Time } \\
\text { (days) }\end{array}$} & Concentration (\%) & $\begin{array}{c}\text { Penicillium spp. } \\
\text { Mycelia growth } \\
(\mathrm{mm}) \text { Mean } \pm \text { SD }\end{array}$ & $\begin{array}{c}\text { Cladosporium spp. } \\
\text { Mycelia growth } \\
(\mathrm{mm}) \text { Mean } \pm \text { SD }\end{array}$ \\
\hline \multirow{4}{*}{5} & 0 & $42 \mathrm{a} \pm 6.9$ & $23 \mathrm{a} \pm 4.9$ \\
\cline { 2 - 4 } & 10 & $31.6 \mathrm{~b} \pm 4.7$ & $18 \mathrm{~b} \pm 2.8$ \\
\cline { 2 - 4 } & 20 & $30 \mathrm{~b} \pm 8.1$ & $15.3 \mathrm{~b} \pm 0.4$ \\
\hline \multirow{4}{*}{7} & 25 & $29 \mathrm{c} \pm 6.61$ & $14.6 \mathrm{c} \pm 12.7$ \\
\cline { 2 - 4 } & 0 & $55 \mathrm{a} \pm 8.1$ & $37.3 \mathrm{a} \pm 6.1$ \\
\cline { 2 - 4 } & 10 & $43.3 \mathrm{~b} \pm 6.2$ & $33.3 \mathrm{~b} \pm 1.2$ \\
\hline \multirow{4}{*}{9} & 20 & $36.3 \mathrm{~b} \pm 5.3$ & $25.3 \mathrm{~b} \pm 4.4$ \\
\cline { 2 - 4 } & 25 & $35.6 \mathrm{c} \pm 7.5$ & $25 \mathrm{c} \pm 12.5$ \\
\cline { 2 - 4 } & 0 & $64 \mathrm{a} \pm 10.1$ & $47.6 \mathrm{a} \pm 6.2$ \\
\hline & 20 & $50 \mathrm{~b} \pm 8.1$ & $38.6 \mathrm{~b} \pm 6.2$ \\
\hline & 25 & $40 \mathrm{~b} \pm 5.4$ & $28.6 \mathrm{~b} \pm 2.7$ \\
\hline
\end{tabular}

Means with different letters in a same column show significant differences as determined by Duncan's multiple range tests $(\alpha=0.01)$ it is (0.066) for Penicillium spp. And (0.114)for Cladosporium spp.

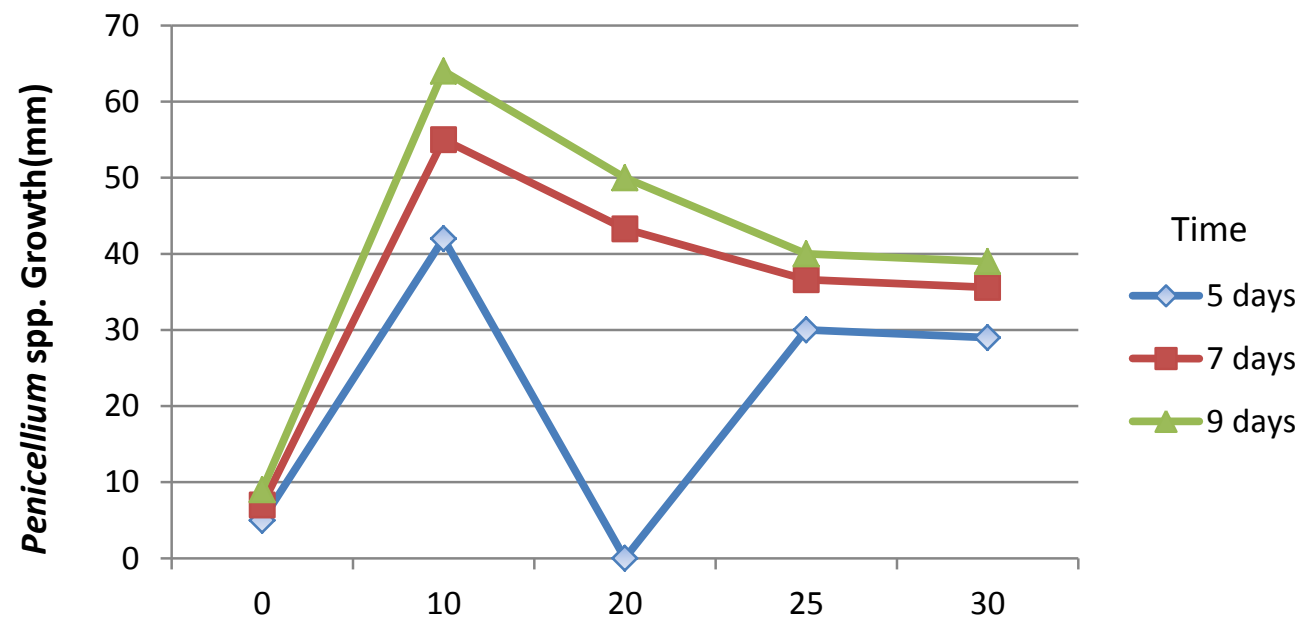

Plant extract concentration \%

Fig. 1. Effect of interactions between Conc. of aqueous extracts of pomegranate and time of incubation on mycelia growth of Penicillium spp. 


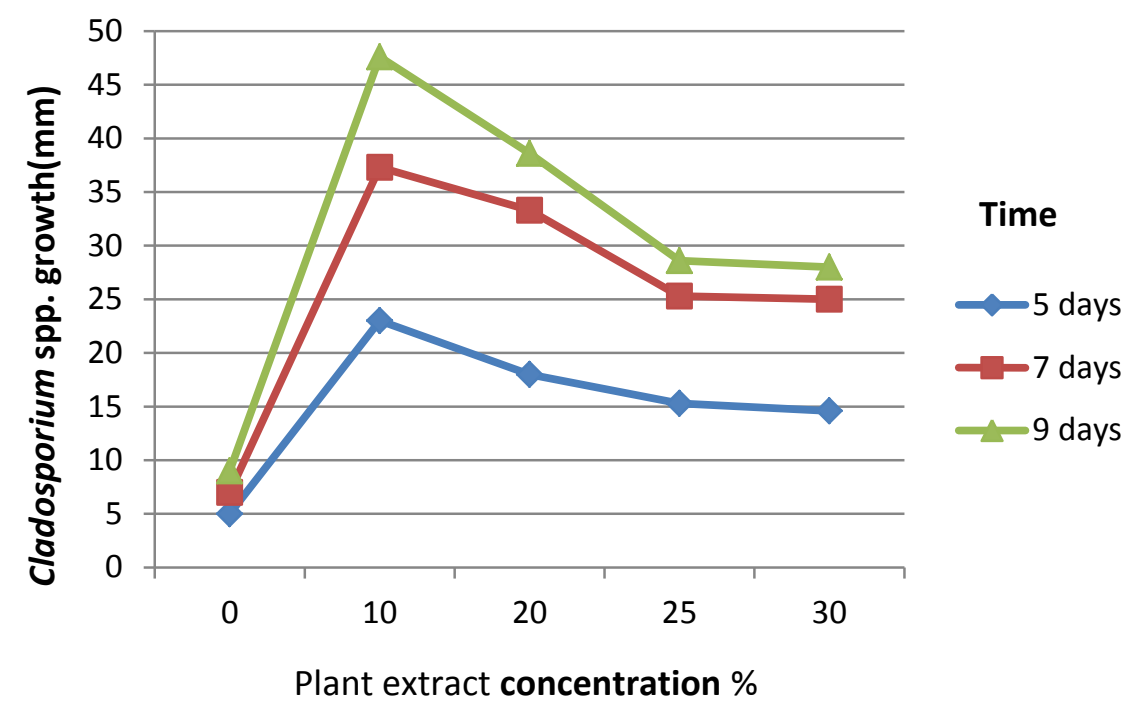

Fig. 2. Effect of interactions between conc. of aqueous extracts of pomegranate and time of incubation on mycelia growth of Cladosporium spp.

\subsection{Effects of Oak Galls Extract on Controlling the Studied Fungi}

Table 3 shows that the aqueous extract of oak galls at all concentrations affected significantly the growth of mycelia of Penicillium spp. and Cladosporium sp. Reduced the mycelia growth of the two fungi to (29-14.6 and 29.6-15.3 mm compare with 42.6 and $23 \mathrm{~mm}$ for the control respectively. Time of incubation also affected the growth of mycelia significantly and the effects of extracts reduced as the time increased. Figure 3 shows that the effect of aqueous extract on the growth of mycelia of Penicillium spp. The growth decreased with time and no differences between the extract concentrations in their effects were observed. (Figure 4) show the mycelia growth was $35-25 \mathrm{~mm}$ after 5 days of incubation and decreased to $24 \mathrm{~mm}$ at $20 \%$ of the extract after 5 days of incubation. The interaction between extract percentages and time is clear and the highest effects were $45 \mathrm{~mm}$ compared with $70 \mathrm{~mm}$ for control after 9 days. 


\section{Macrothink}

Journal of Biology and Life Science

ISSN 2157-6076

2015, Vol. 6, No. 1

Table 3. effect of aqueous extract of oak gall on Penicillium spp. and Cladosporium spp. Mycelia growth.

\begin{tabular}{|c|c|c|c|}
\hline \multicolumn{2}{|c|}{ Treatment } & \multicolumn{2}{c|}{ Fungal species } \\
\hline $\begin{array}{c}\text { Time } \\
\text { (days) }\end{array}$ & Concentration (\%) & $\begin{array}{c}\text { Penicillium spp. } \\
\text { Mycelia growth } \\
(\mathrm{mm}) \text { Mean } \pm \text { SD }\end{array}$ & $\begin{array}{c}\text { Cladosporium spp. } \\
\text { Mycelia growth } \\
\text { (mm) Mean } \pm \text { SD }\end{array}$ \\
\hline \multirow{4}{*}{5} & 0 & $42.6 \mathrm{a} \pm 6.0$ & $23 \mathrm{a} \pm 4.9$ \\
\cline { 2 - 4 } & 10 & $31.3 \mathrm{~b} \pm 5.7$ & $16.3 \mathrm{~b} \pm 2.0$ \\
\cline { 2 - 4 } & 20 & $29.6 \mathrm{~b} \pm 8.9$ & $16 \mathrm{~b} \pm 2.1$ \\
\cline { 2 - 4 } & 25 & $29 \mathrm{c} \pm 3.9$ & $14.3 \mathrm{c} \pm 3.0$ \\
\hline \multirow{4}{*}{7} & 0 & $55 \mathrm{a} \pm 7.0$ & $37.3 \mathrm{a} \pm 6.1$ \\
\cline { 2 - 4 } & 10 & $39.6 \mathrm{~b} \pm 7.0$ & $27.3 \mathrm{~b} \pm 1.2$ \\
\cline { 2 - 4 } & 20 & $34 \mathrm{~b} \pm 7.4$ & $24.6 \mathrm{~b} \pm 3.8$ \\
\hline \multirow{4}{*}{9} & 25 & $33.3 \mathrm{c} \pm 5.4$ & $17.6 \mathrm{c} \pm 3.8$ \\
\cline { 2 - 4 } & 0 & $64 \mathrm{a} \pm 5.6$ & $47.6 \mathrm{a} \pm 3.8$ \\
\cline { 2 - 4 } & 10 & $46.6 \mathrm{~b} \pm 8.8$ & $31 \mathrm{~b} \pm 1.6$ \\
\cline { 2 - 4 } & 20 & $40 \mathrm{~b} \pm 9.3$ & $29.6 \mathrm{~b} \pm 5.2$ \\
\hline
\end{tabular}

Means with different letters in a same column show significant differences as determined by Duncan's multiple range tests $(\alpha=0.01)$ it is $(0.035)$ for Penicillium spp. And (0.33)for Cladosporium spp.

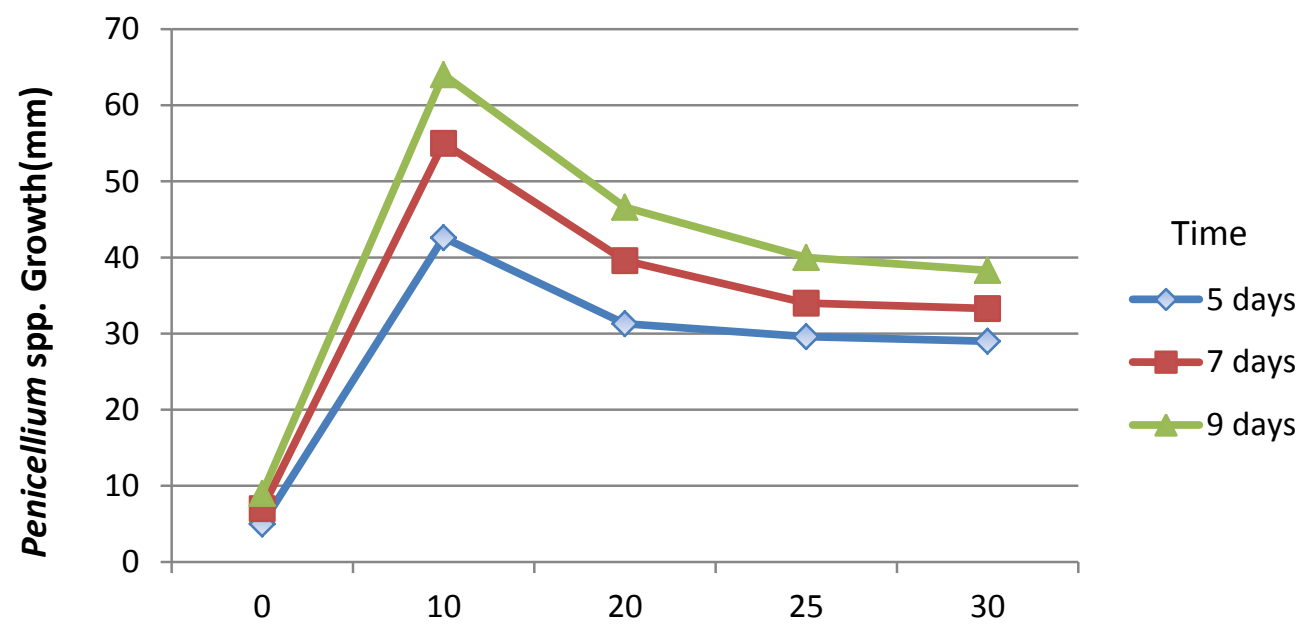

Plant extract concentration \%

Fig. 3. Effect of interactions between conc. of aqueous extracts of oak and time of incubation on mycelial growth of Penicillium spp. 


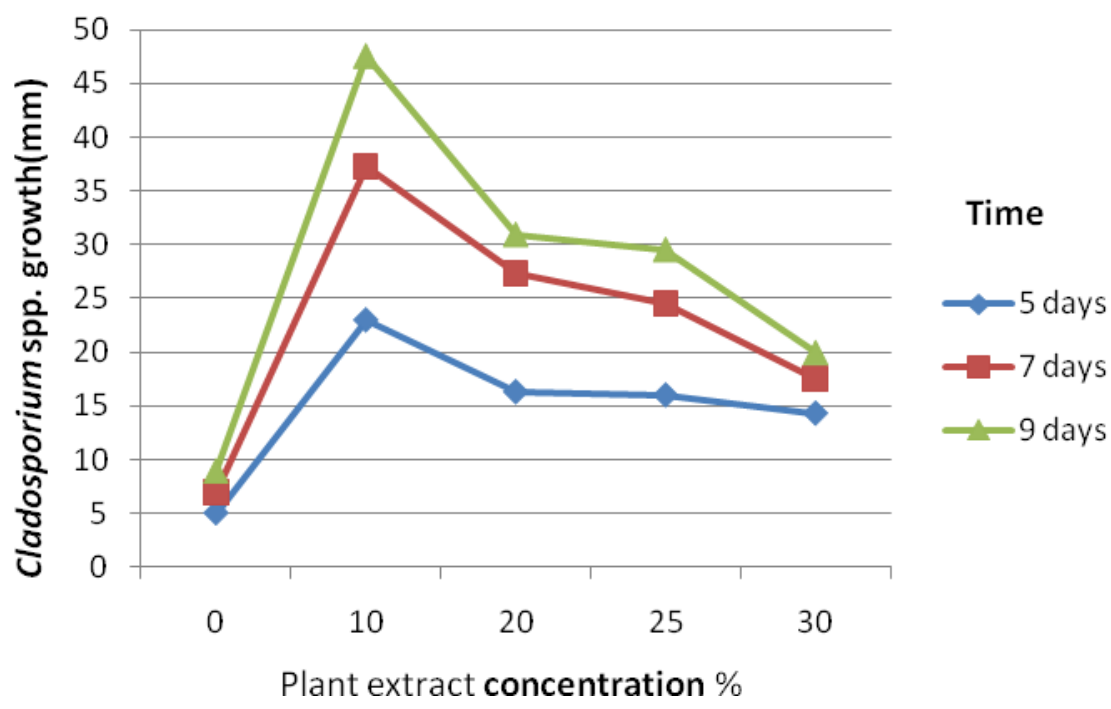

Fig. 4. Effect of interactions between conc. of aqueous extracts of oak and time of incubation on mycelia growth of Cladosporium spp.

\section{Conclusion}

The aqueous extract of pomegranate affected significantly the growth of mycelium of Penicillium spp. and Cladosporium sp by reducing the mycelial growth Time of incubation also affected the growth of mycelia significantly and the effects of extracts reduced as the time increased.

\section{References}

Aba Alkhail, A. A. (2005). Antifungal activity of some extracts against some plant pathogenic fungi. Pakistan J. Biol. Sci. 8(3), 413-417. http://dx.doi.org/10.3923/pjbs.2005.413.417

Aqil, F., M. Zahin, I. Ahmed, M. Owais M. S. A. Khan, S. S. Bansal \& S. Farooq, (2010). Antifungal Activity of Medical Plant Extracts and Phytocompounds: A Review. In: Combating Fungal Infections: Problem and Remedy, Ahmad, I., M. Owais and M. Shahid (Eds.). Springer-Verlag, Berlin Heidelberg, pp: 449-485.

Basm, F. D., Khalil, A. (2007). The inhibitory effect of extracts from Jordanian medical plants against phytopathogenic fungi. Plant Path. J. 6(2), 191-194. http://dx.doi.org/10.3923/ppj.2007.191.194

Bocklisch H, Otto B. (2000). Mycotic diseases in fish. Mycoses; 43, 76-8.

Dixon DM, Polak-Wyss A, ( 1991). The medically important dematiaceous fungi and their identification. Mycoses; 34, 1-18. http://dx.doi.org/10.1111/j.1439-0507.1991.tb00613.x

Harborne, J. B. (1984). Phytochemical Methods. A Guide to Modern Techniques of Plant Analysis. Chapman and Hall.2nd edn. London, New York, 288 p.

Hoog GS, Queiroz-Telles F, Haase G, Fernandez-Zeppenfeldt G, Angelis DA, van den Ende A, Matos T, Peltrohe-Llacsahuanga H, Pizzirani-KleinerAA rainer J, Richard-Yegres N, Vicente V, Yerges F. (2000). Black fungi: clinical and pathogenic approaches. Med Mycol; 38:243-50. 
http://dx.doi.org/10.1080/mmy.38.s1.243.250

Lin, K. C. (1981). Resistance of ten tree species to sulfur dioxide. Bull. Taiwan For. Res. Inst. $349,14$.

Mitra, S. R., Choudhuri, A., \& Adityachaudhury, N. (1984). Production of antifungal compounds by higher plant a review of recent researches. Plant physiol. Biochem. 1. 53-77.

Paaverurve, V. M., Raal, A. (2010). Total tannin content in distinct Quercus robur L. galls. $J$. Med. plant Res. 4(8), 702-705.

Sarmamy A. O. I.; Saleem, Z. K. (2009). Impact of Ficus carica L. leave extracts on some pathogenic fungi.10th Arab Conf. P. Prot. Beirut, Lebanon.

Sarmamy, A. O. I. (2001). Effect of some weed extracts on the growth of some pathogenous bacteria. Dissertation, Baghdad Univ., Baghdad, Iraq.

Sarmamy, A. O. I.; Al-Juboory, B. A. (2005). Effect of rhubarb extracts on the growth of some pathogenic bacteria. Proc. 4th Int. Con. Biol. Sci. (Botany), 141-145, Tanta, Egypt.

Seeram, N. P.; Henning, SM.; Zhang, Y.; Liz, S. M. ; Heber, D. (2006). Pomegranate juice ellagitannin metabolites are present in human plasma and some persist in urine for up to 48 hours. J. Nutr. 136 (10), 2481-5.

Vonshak, A.; Barazani, O.; Sathiyamoothy, P.; Shalev, R.; Vardy, D.; Golan-Goldhirsh, A. (2003). Screening of south Indian medical plants for antifungal activity against cutaneous pathogens. Phytother. Res. 17, 1123-1125. http://dx.doi.org/10.1002/ptr.1399

Witte, W. (1998). Medical consequence of antibiotic use in agricultural. Science. 279, 1153-1154. http://dx.doi.org/10.1126/science.279.5353.996

\section{Copyright Disclaimer}

Copyright for this article is retained by the author(s), with first publication rights granted to the journal.

This is an open-access article distributed under the terms and conditions of the Creative Commons Attribution license (http://creativecommons.org/licenses/by/3.0/). 